\section{Provider attitudes and management regarding returning to drive after concussion}

The annual incidence of sports and recreational-related concussion in the USA is $1.6-3.8$ million. ${ }^{1}$ Just as concussions are common in adolescents, so are motor vehicle crashes. Asif et $a l^{2}$ recently showed that motor vehicle crashes are the most common cause of sudden death in collegiate athletes across levels of competition, gender, race and sport. ${ }^{2}$

Driving is a complex task that requires coordination of cognitive, visual and motor skills as well as higher cognitive skills such as concentration, attention, visual perception, insight and memory. Concussion may induce a variety of cognitive perturbations that might compromise driving ability - including physical symptoms such as headache or dizziness, cognitive dysfunction, emotional lability, as well as impaired sleep. Though there are no published data on driving after concussion, there are published data regarding driving after mild traumatic brain injury (mTBI). Patients with mTBI were significantly slower to respond to traffic hazards than comparator patients with minor orthopaedic injuries. ${ }^{3}$ Even more concerning, half of the individuals recovering from mTBI did not intend to moderate their driving exposure post-injury. ${ }^{4}$ Physicians represent a key stakeholder in making return to driving decisions, but there have been no published articles examining the current practices and attitudes of physicians who treat concussions regarding return to drive. Therefore, we reported current physician practices and attitudes regarding driving after concussion.

Approximately 2100 members of the American Medical Society for Sports Medicine were contacted twice via email and invited to complete an anonymous, 24 question on-line survey. The survey consisted of questions concerning demographic data of the provider, attitudes regarding driving while concussed and actual management practices of driving after a concussion. While 385 ( $\sim 18 \%$ response rate) of medical providers responded, only providers who managed at least one concussion per month/12 per year were included in the study ( $n=333)$.
In this study of physician attitudes and practices regarding post-concussive care, the majority $(83 \%)$ of responding physicians felt that athletes were at an increased risk of motor vehicle crashes (see online supplementary table 1). Despite recognition that concussion may put drivers at increased risk, fewer than half $(49 \%)$ of the physicians indicated they 'almost always' counsel patients regarding driving after concussion. In comparison, $85 \%$ of responders 'almost always' counsel about screen use (television, computer, phone) following concussion. A majority (82\%) of participants indicated they did not implement testing to determine whether or not an athlete is ready to return to drive, while $30.4 \%$ of responders indicated they do not have clear return-to-drive criteria.

Driving restrictions can have significant impacts on the mental and fiscal well-being of individuals. Healthcare professionals may be reluctant to advise patients on this issue for fear of creating adversities for the patient or family. Furthermore, physicians often lack the knowledge and training to make return-to-drive decisions. ${ }^{5}$ Future research should be directed to better understand the effects of concussion on driving. Driving simulators are increasingly being used in rehabilitation settings and have the potential to be used to screen, assess and provide interventions for patients with concussion. ${ }^{6}$

Motor vehicle crashes are a leading cause of death for adolescents and young adults for which concussions may place athletes at increased risk. Despite this increased risk, a majority of physicians in our sample did not routinely counsel athletes about the risks of driving, and many felt they do not have clear return-to-drive criteria. It is plausible that counselling is not offered due to the paucity of data regarding driving after concussion. Further research is needed to determine the risk of driving after concussion with the long-term goal of establishing clear return-to-drive guidelines.

John A Lucas, ${ }^{1}$ Justin B Moore, ${ }^{2,3}$ Stephen Davis, ${ }^{2}$ Johnell 0 Brooks, ${ }^{4}$ Christopher Miles ${ }^{2}$

${ }^{1}$ Sports Medicine Institute, Spartanburg Regional Healthcare System, Spartanburg, South Carolina, USA ${ }^{2}$ Department of Family \& Community Medicine, Wake Forest School of Medicine, Wake Forest Baptist Medical Center, Winston-Salem, North Carolina, USA

${ }^{3}$ Department of Epidemiology \& Prevention, Wake Forest School of Medicine, Wake Forest Baptist Medical Center, Winston-Salem, North Carolina, USA ${ }^{4}$ Department of Automotive Engineering, Clemson University International Center for Automotive Research, Greenville, South Carolina, USA
Correspondence to Dr. John A Lucas IV, Sports Medicine Institute, Spartanburg Regional Healthcare System, Spartanburg, SC 29301, USA; jlucas@srhs.com

Funding This research received no specific grant from any funding agency in the public, commercial or notfor-profit sectors.

Competing interests None declared.

Patient consent Not required.

Ethics approval Institutional review board.

Provenance and peer review Not commissioned; externally peer reviewed.

\section{(6) OPEN ACCESS}

Open access This is an open access article distributed in accordance with the Creative Commons Attribution Non Commercial (CC BY-NC 4.0) license, which permits others to distribute, remix, adapt, build upon this work non-commercially, and license their derivative works on different terms, provided the original work is properly cited and the use is noncommercial. See: http://creativecommons.org/licenses/ by-nc/4.0/

(c) Article author(s) (or their employer(s) unless otherwise stated in the text of the article) 2019. All rights reserved. No commercial use is permitted unless otherwise expressly granted.

- Additional material is published online only. To view please visit the journal online (http://dx.doi.org/ 10.1136/bjsports-2018-099118).

\section{A) Check for updates}

To cite Lucas JA, Moore JB, Davis $\mathrm{S}$, et al. Br J Sports Med 2019;53:495.

Accepted 14 February 2018

Published Online First 12 March 2018

Br J Sports Med 2019;53:495

doi:10.1136/bjsports-2018-099118

\section{REFERENCES}

1 Langlois JA, Rutland-Brown W, Wald MM. The epidemiology and impact of traumatic brain injury: a brief overview. J Head Trauma Rehabil 2006;21:375-8.

2 Asif IM, Harmon KG, Klossner D. Motor vehicle accidents: the leading cause of death in collegiate athletes. Clin J Sport Med 2013;23:439-43.

3 Preece MH, Horswill MS, Geffen GM. Driving after concussion: the acute effect of mild traumatic brain injury on drivers' hazard perception. Neuropsychology 2010;24:493-503.

4 Preece MH, Geffen GM, Horswill MS. Return-to-driving expectations following mild traumatic brain injury. Brain Inj 2013;27:83-91.

5 Brooks JO, Dickerson A, Crisler MC, et al. Physician knowledge, assessment, and reporting of older driver fitness. Occup Ther Health Care 2011;25:213-24.

6 Classen S, Brooks J. National highway traffic safety A, American occupational therapy A. Driving simulators for occupational therapy screening, assessment, and intervention. Occup Ther Health Care 2014;28:154-62. 